\title{
Social movements and the transformation of teachers' work: case studies from New Zealand
}

\author{
Ronald G. Sultana
}

\begin{abstract}
The major aim of this article is to explore the potential of teachers as transformative agents within schools. The study first looks at theoretical perspectives which analyse both the class location of teachers as well as the kinds of relationships and structural constraints into which they enter - both in their pre-service training, and throughout their work as teachers. The paper then presents ethnographic data to argue that despite the overwhelming and hegemonic restraints on teachers, when they, individually and/or collectively, are inspired by social movements outside of the school, then total institutional and ideological incorporation is less likely to take place. Case studies are presented to illustrate how such politicized teachers and schools struggle to establish a space in favour of progressive and democratic agendas.
\end{abstract}

\section{Introduction}

This paper attempts to explore some of the inroads made by educational activity into the promotion of more democratic and equitable social arrangements. The specific focus is therefore to find out to what extent and under which conditions counterhegemonic schooling takes place. The relevant issues are first located in their theoretical context. Here, perspectives on teachers' work are traced in order to discover the structural and cultural constraints - as well as possibilities - which define teachers' response to the invitation to become allies in the task of bringing about progressive change within, and outside of, schools. The issues raised in a theoretical fashion in Part One are then explored in ethnographic data in Part Two, where case studies of transformative education observed throughout 1986 in three high schools in New Zealand are contextualized, described, and analysed.

Efforts are made throughout to point out the significance, for educational researchers elsewhere, of both case studies and the theory grounded in ethnographic data arising in a New Zealand context. While Eurocentric readers might consider New Zealand too distant, geographically and culturally, to have any relevance to their particular concerns, it will become apparent that a number of parallels can be drawn between that Australasian nation and much of the rest of the 'Western world'. In

Ronald Sultana is a lecturer in the sociology of education at the Department of Educational Studies, University of Malta. 
particular, the economic crisis in New Zealand has had much the same effect on social and educational policy-making, where technocratic rationality and 'property rights' rather than 'person rights' have been given priority. As a result, social movements outside and within the educational camp attempt to promote their own particular, often oppositional, agendas. In this regard, New Zealand represents a splendid social laboratory. As its systems are small, it is easier for the researcher to grasp with clarity the processes of social reproduction and transformation that are the focus of this paper.

\section{Part one}

\section{Theoretical context}

Educational scholars from the Left who are sensitive to the link between formal schooling and the wider social order, and who are critical of both, have been attempting to explore the 'relatively autonomous' space of the school in order to discover ways in which educational activity can foster transformation. Attention has been focused on school systems generally as well as on the actors involved in the educational encounter in an effort to formulate a 'language of possibility'. On taking a brief look at recent theorizing about teachers' work, it becomes obvious that there have been a number of important developments over the past decade and a half. From an over-deterministic account, which saw teachers as implicated in the task of the ideological, cultural and economic reproduction of an oppressive social order, we have now moved to accounts that encourage teachers to become politically aware of the implications of their work and to act positively and pro-actively in the direction of social change within and outside of schools (Giroux, 1988).

Both the earlier structuralist-functionalist approach and the more recent emphasis on the relative autonomy of actors and the depiction of schools as sites of struggle and contestation over meaning (Apple, 1982) are useful in the present attempt to tease out some hypothesis about the possiblity that teachers can become the transformative intellectuals that critical scholars would like them to be. If current work is at all to build on the existing wealth of empirical and theoretical research, it has to acknowledge both the constraints and the possibilities, the boundaries and the cracks in these structural limitations.

Any theory of action has to reconnoitre critically these boundaries, the extent to which, and the conditions under which, teachers will treat students as critical agents, will problemize knowledge, utilize dialogue, and make knowledge meaningful, critical, and emancipatory. If we were to follow the structuralist path, we would then search for comparative perspectives on teachers as class agents, attempt to analyse these workers' position in a stratified society and deduce their political potential from that. It quickly becomes obvious that, as Sachs and Smith (1988, p. 429) note, teacher recruitment in a variety of countries is made from the 'middle classes', a 'euphemism for relatively conservative attitudes and beliefs, for an orientation into a bourgeois discourse and "habitus".

A more sophisticated approach to teachers as class agents would make use of Poulantzas' (1975) notion of the 'new petty bourgeoisie', and would indicate that teachers' class allegiance can change over time. Thus, with increasing proletarianization of their work, teachers lose many of the extrinsic rewards they usually associate with their profession, and hence might become increasingly critical of capitalism so that 'as the crisis [in capital accumulation] deepens, the bourgeoisie will find in [them] an increasingly unreliable ally' (Steven, 1978, p. 125). Moreover, as Cole (1984)

134 Research Papers in Education Volume 6 Number 2 
suggests, the legitimization crisis leads to a motivation crisis in students, so that even intrinsic rewards, such as favourable relationships with students, are lost. Carlson (1987) suggests that factors such as these tend to push teachers towards industrial unionism and direct confrontation with the capitalist state, which fact draws them closer to an identification with the political interests of a broad working-class movement.

Recent theorizing about teachers as class actors has preferred this more complex approach and to ask, as Ashendon et al. (1987, p. 256) do for instance, not 'In which class location are teachers?' but rather 'Into which class relations do teachers enter? How far are these relations being formed by this person's activity?' This leads to a culturalist view of classes where occupational groups and individuals are not seen as merely analytic abstractions, but rather as "historically embedded agents of action, [whose] actions and beliefs have real consequences that cannot be totally determined' (Carlson, 1987, p. 292). This leads us towards an attempt to get 'accurate bearings on the social situations of teachers, the constraints they work under, and the possibilities open to them' (Connell et al., 1982, p. 206).

However, when we do take a close look at the social situations and relations into which teachers enter, what strikes us are more the constraints than the possibilities. Such limitations are experienced by teachers generally, for, as Sachs and Smith (1988) argue, teachers share many similar conditions of the same work situation, and they experience the same basic concerns and problems. In this way, a teacher culture is created despite the fact that each teacher has a personal history, predispositions and habits of thought. Among the variety of shared conditions and constraints over which teachers have little control, Sachs and Smith mention the following 'givens': class size, school timetables, the education of persons who have not necessarily chosen to be at school, a hidden pedagogy, a concern with what works and hence an instrumental approach to their work rather than one guided by goals and ends, the organization of the school (so that when the teacher exercises autonomy, s/he does so within the conditions set by the institutional structure), and anticipatory socialization of those individuals entering teaching.

Added to this is the prevalence of what Hargreaves (1984) calls the "culture of individualism' among teachers, their 'humanistic, child-centred and psychologistic conception of "teaching" and "learning"" (Sachs and Smith, 1988, p. 427), and their belief that 'practice counts, theory doesn't' (Hargreaves, 1984). One and all make teachers particularly unaware of the relationship between schooling and the social order.

As this substantive exploration of counter-hegemonic education is located in New Zealand, it is relevant to point out that both structural-functionalist as well as culturalist analyses of teachers' work have been carried out in that country, and that the results appear to be similar to those cited above. Ramsay (1983a), referring to his own research evidence and that of others, concludes that New Zealand teachers are drawn from the socio-economic élites of the country, that is, from white, middle- and upper middle-class groups, a recruitment marked by docility, conservatism and critical unreflexiveness. Braithwaite (1984) found that teacher recruitment from 'lower' class groups has declined in recent years. The conservatism of New Zealand teachers has been documented by Boshier (1973) and Ramsay (1978), among others, while studies by Mercurio (1975), Ramsay (1978) and Battersby (1981) have shown how teachers are socialized into accepting the prevalent status quo in the schools where they work, even if they were initially critical of it. Tower (1978) observed that students enrolling in programmes in politics and philosophy were prohibited, in an unofficial manner, from entering teachers' colleges. More recently, I discovered, through a key informer on a teachers' college board, a planned strategy by religious 
fundamentalist groups to place as many of their young members as possible into teacher training.

Such general patterns in teacher recruitment and socialization seem to suggest, therefore, that teachers can hardly be expected to embark on counter-hegemonic activities within schools. While schools, like other social sites, have a multiplicity of contestual voices, there seems to be little doubt that reproductive and hegemonic ones are the most prevalent, both because of the class location of teachers as well as because of the sets of social relationships and power structures in which they are constrained to negotiate, produce and reproduce meaning.

It will be argued throughout this paper, however, that teachers' political consciousness and activities will increasingly tend towards progressive rather conservative agendas if they are themselves caught up in democratic social movements, external to the school, that impinge on their perceptions and commitments, both individually and collectively. This proposition will be explored in ethnographic data, drawing from my research in New Zealand high schools (Sultana, 1987). A brief description of this study is first given before passing on to a detailed account of the ways in which teachers and schools acted in transformative ways.

\section{Research context}

Throughout 1986 I carried out an ethnographic research project in three secondary schools in a provincial city of the North Island of New Zealand. The focus was to appraise critically the formal and informal school-to-work messages given by the structures, content and pedagogy prevalent within the three educational establishments, and the reception such messages were given by students. The study therefore set out to make explicit the content, form, structure and framing of what counts as knowledge, as well as whose interests this knowledge serves. A grounded-theory method (Glaser and Strauss, 1967) was used in the collection of data, and the construction of substantive and formal-theoretical propositions from the emerging data was guided by neo-Marxist and culturalist perspectives as exemplified in the work of, inter alia, Willis (1977), Anyon (1980), and Griffin (1985). While the detailed exploration of both transmission and reception of messages remains the original contribution of the study and has been described in various publications, the focus of this particular article is on the messages given by teachers to students about the world of work, and which therefore have some significance regarding the ideological and political commitments of teachers.

In all, 182 out of a total of 197 school days were spent carrying out observations in the field. Staffrooms, classrooms, assemblies, parents' evenings, school camps, work-exploration placements, and recreation programmes were all considered to be sites for data collection. Some 151 lessons (including social studies, careers and transition education programmes, English, history and typing lessons) were observed. Fifty teachers (of whom 23 were women, and three Maori) were interviewed individually at least twice - often up to 10 or more times - throughout the year. Three hundred and seventy students (of whom 187 were women, and 87 Maori) were interviewed in post-lesson/unit sessions.

The three secondary schools were chosen to represent different and contrasting educational climates. 'Two of these schools, here referred to as 'All Girls' High' and 'Co-Ed High', were large state schools catering for most if not all the city's ethnic (mainly European, Maori, Pacific Island and Asian) and social-class groups. 'All Boys' College' differed from the other two schools in various ways: it was an integrated Catholic school catering for predominantly European and middle-class

136 Research Papers in Education Volume 6 Number 2 
males. It was also the smallest school in the sample, having a population of 450 compared to the 950 for the girls' school, and 1400 for the coeducational one.

While a more detailed picture of the three schools will emerge as a range of issues is addressed in the remainder of this paper, it is important to point out that within a single article it is well-nigh impossible to do justice to the complex inter- and intraschool similarities and differences observed. These limits also do not allow detailed exploration of the overwhelmingly hegemonic activity of teachers observed in the three schools. The focus in this context is on transformative schooling, while thick description' on socially reproductive activity in these three schools has been presented elsewhere (see Sultana, 1988a,b, 1989, 1990a,b,c). Suffice it to point out that generally, and with regard to school-to-work messages in particular, schools and teachers represented the industrial, rather than democratic, imperative (see Carnoy and Levin, 1985) through knowledge forms, knowledge content, and classroom social relations. The ideological, economic, and cultural reproductive functions discovered in the three schools parallel those found in other studies carried out in New Zealand (see Ramsay, 1983b; Archer and Openshaw, 1986) and elsewhere (see LindBrenkman, 1983; Shilling, 1987 among others).

There is therefore some agreement with Sachs and Smith (1988) when they conclude that teachers and schools are characterized by uniformity rather than pluralism. Yet if, in the tradition of the critical theorists of the Frankfurt school, we are to try to draw that fine line between what is and what could and should be, it is of utmost theoretical and strategic importance to identify, study and understand the transformative teacher and school. Various research studies, such as those of Anyon (1980, 1981) and Gaskell (1986), attribute an internal homogeneity to schools and teachers, failing to identify competing voices. My own research attempted to do justice to the complexity of social beings and institutions. In this particular paper I explore one facet of this complexity by departing from a description of the mainstream reproductive processes in schools to present an account of the individual and collective efforts of teachers in trying to establish progressive, at times radical, agendas in the general ethos, curricula and socialization processes of their particular schools.

\section{Part two}

\section{Transformative efforts of schools and teachers}

Despite the generally hegemonic nature of the schools observed, it was noted that when teachers were individually or/and collectively caught up in a dynamic interaction with progressive social movements, then their ideological commitment departed from conservative and, at times, even reactionary grounds, and moved closer to liberal and occasionally to radical ones. The link between education, social transformation and social movements has been recently formulated by Carnoy and Levin (1985), although there had been earlier statements to the effect that democracy has not been the result of individual action within the classroom as much as pressures exerted by social movements about particular issues. Carnoy $(1983$, p. 401) had in fact stated that 'Democracy has been developed by social movements, and those intellectuals and educators who were able to implement democratic reforms in education did so in part through appeals to such movements.'

Schools and teachers cannot avoid such interaction with the 'public sphere' because, as Carnoy and Levin (1985, p. 4) argue: 'As both a product and a shaper of social discord, the school is necessarily caught up in the larger conflicts inherent in the 
capitalist economy and the capitalist state.' It was observed in the larger study from which this paper draws that once teachers became involved in the wider struggle for democracy, it became increasingly difficult for them to maintain their "culture of individualism' within the classroom. Such teachers were therefore better armed to resist the near total institutional and ideological incorporation which generally characterizes this group of workers.

The next sections will explore this observation in ethnographic data referring on the one hand to schools as political institutions and on the other to individual teachers as political actors. A variety of social movements, not all of them progressive, are wielding some influence in forming the social consciousness and subjectivities of contemporary New Zealanders. Such movements are considered to represent an important democratic issue, and all have in common a moral force stemming from 'their promise to free their participants from the deeply felt unjust (threat of) deprivation of material necessities, social status, and cultural identity' (Frank and Fuentes, 1987, p. 1507). Social movements need to be located within the wider historical development of capitalism in New Zealand. This contextualization is important for, as Frank and Fuentes have argued, social movements, their membership, mobilization and strength tend to be cyclical because "the movements mobilise people in response to (mostly against, less for) circumstances, which are themselves cyclical'. They also argue (p. 1505) that 'when the economic downturn most detrimentally affects people's livelihood and identity, the social movements become more offensive, progressive, and socially responsible'.

Such cyclicality has also been theorized in relation to education by Carnoy and Levin (1985, p. 41), who have argued that:

in historical periods when social movements are weak and business ideology strong, schools tend to strengthen their function of reproducing workers for capitalist workplace relations and the unequal division of labour. When social movements arise to challenge these relations, schools move in the other direction to equalize opportunity and expand human rights.

In the particular historical conjuncture which was 'caught' by my study represented above all by a severe crisis in capital accumulation - there was evidence of this struggle between giving in to increasingly strong pressures for the use of schools for the reproduction of the work-force on the one hand and for the promotion of a democratic and equitable social order on the other. While it is true that hegemonic pressures often held the upper-hand, careful observation revealed contestual, individual and collective voices that echoed the concerns of democratic social movements in the wider, public sphere. Such voices, politicized by the very same economic crisis, were in the New Zealand of 1986 becoming increasingly strident in asserting their agendas in multiple sites in the social formation.

In what follows, evidence is given of the transformative potential of social movements in New Zealand and the way that their resonance was being felt within the three schools in question. Here, issues promoted by the different social movements were occasionally or systematically emphasized and taken into consideration by within-schools policy-makers (as represented by administrative staff and Boards of Governors), by the staff as a whole (during staff meetings and general discussions about the those of the school), by subject teachers (such as during meetings with heads of the respective subject departments), and by individual teachers in the classroom.

The different social movements that informed teachers' and schools' individual and/or collective initiatives include trade unionism, the ethnic rights movement,

138 Research Papers in Education Volume 6 Number 2 
feminism, liberationism, and the Peace Movement. These social movements will serve to organize the data and to bring home a number of important points to those interested in the transformative potential of education. The material conditions from which each movement springs are placed in their New Zealand context, and then the ways in which such movements affect school practices are examined.

\section{Trade union movement}

I mention this first not because it was the most influential movement in the three schools observed, but because of my persuasion - following analyses such as those provided by Wright (1983) and Miliband (1987) - of the centrality and priority of class in explaining oppression and in pointing towards transformation. Any discussion of trade union activity as a movement representing workers' rights as a class needs to be historically and critically sensitive to the way working-class and union(-ization) movements have been coopted and corrupted by management, and especially so in the current phase of monopoly capitalism. However, despite the fact that union leaders have, in Mills's words, often served as 'managers of discontent', the potential always exists that trade unions might become political (Carlson, 1987).

The insistence on the centrality of class is particularly pertinent to the New Zealand context where, as Jones (1986, p. 87) notes, despite analysis of the class structure as carried out by sociologists like Bedggood (1980) and Spoonley et al. (1982), nevertheless '... the continuing official and popular ideology/mythology is that New Zealand is a largely unstratified and egalitarian society'. In New Zealand there is little sign of class consciousness, although it could be argued that with the increasing differences between the 'haves' and the 'have nots', as Waldegrave and Coventry (1987) have documented, increasingly there exist the material conditions needed to change the New Zealand working (and unemployed) class-of-itself into a class-foritself.

The issue of class needs to be given its central place because ethnicity - and the high profile biculturalism has been given by the Lange Labour Government - has tended to mystify the structure of inequality based on class. Within education, Lauder et al. (1985) have provided research evidence to show that the existence of inequality is associated with class background over and above ethnic background, even though the working-class and ethnic 'minority' groups converge in their limited access to material resources. Class, therefore, parades around in ethnic clothing.

As with Ramsay and his colleagues' (1983) findings in their own study, teachers in all three schools were more willing to discuss ethnic rather than class oppression. Hardly ever did the notion of class crop up throughout the scores of lessons observed during the year. While students occasionally spoke of classmates as being of a 'higher' or 'lower' class, there was generally no understanding of the relationships between material conditions and structures of power in New Zealand society.

One way of showing the extent of this lacuna is to give an account of the few times that a possible space for giving messages about class cropped up in work education programmes. I am referring here to specific messages given, or more frequently, not given, by teachers about trade unions. As suggested earlier, most of the school-towork messages given in the three schools were hegemonic. Hegemonic, too, were the messages and topics not tackled. As Eisner (1985, p. 97) has argued, what is not taught may be as educationally significant as what is taught, "because ignorance is not simply a neutral void; it has important effects on the kinds of options one is able to consider, the alternatives one can examine, and the perspectives from which one can view a situation or a problem'. 
The schools' and teachers' 'selective tradition' (Williams, 1978) meant that students did not have any pictures of employers' exploitation of workers, and neither could they develop an historical perspective on working-class struggles in New Zealand. It is important to point out that many teachers avoided discussing trade union activity with their students in order to avoid controversial issues and as a form of 'survival strategy' to ensure their own comfort rather than for any particular educational or ideological ends. As one teacher explained, 'Trade unions are a hot potato in New Zealand. Not many teachers [like to] talk about them in class.' Another important reason for this structured silence about the issue was, as has already been intimated in the theoretical introduction of this paper, the general social-class background of the teachers themselves, and their identification with specific class interests. A social studies teacher from All Girls' High expressed this well:

I think a lot of teachers keep away from teaching about unions because they are themselves personally ambivalent in their feelings towards them. If you said to a teacher 'You belong to a trade union', they would be very hostile. It's a class thing to some extent... that if you are waged, or not especially well-qualified, you belong to a trade union, and if you are on a salary, and are reasonably well-paid, then you belong to an association.

These considerations help to explain why it was that technical teachers were found to be more ready than other teachers to talk about unions in the classroom, and to do so in a positive way. Their anticipatory socialization and social-class experiences were different, as they had been involved in waged labour in industry and participated in direct class struggle themselves. A technical teacher from All Boys' College explained:

Well, I'm a carpenter... I've been involved in some monumental strikes, and I was off work for six weeks one time. I say in the classroom that if it wasn't for the unions, we'd still be back in our grand parents' time where you were sitting under a hedge waiting for the sun to come up to start work ... and at half-past ten in the morning the person employing you might say: 'Well hurry, get lost!!' And that would be your luck for that day. And if it started to rain you'd carry on working, and when dark came, then you would go home... It's really the unions who have brought about a lot of social change, and they are quite reasonable in the main... So I promote them.

A Co-Ed High technical teacher felt very strongly about trade union education in schools. As future workers, students needed to know where to get protection '.. because there are some very unscrupulous employers around. We should tell them that. I think trade unions should be on the curriculum. I'm sure it should'. Only one of the five technical teachers interviewed felt he should not address the issue of trade unionism with students. Interestingly enough, this teacher, unlike the others, had been an employer rather than an employee before becoming a teacher.

The only other case where class issues were raised was by Ms Woods, a teacher of social studies and economics at All Girls' High, and perhaps the most radical teacher in all three schools observed. Her involvement with a number of social movements, and her commitment to national politics (as a Labour candidate, for instance), made her very critical of what was taking place within schools. She was the only teacher to deal with trade unionism as a unit in itself, spending much of the first school term on the subject. She spoke about the different methods of production through the ages, showing the conditions of work bred from the Industrial Revolution. She concen-

140 Research Papers in Education Volume 6 Number 2 
trated on New Zealand examples of trade union activity and workers' efforts to obtain rights and good conditions of work. She presented her students with various case studies taken from New Zealand courts where unions helped workers who were unjustly treated by their employers. Students were given hand-outs about laws dealing with workers' jobs, pay, conditions, rights at work and negotiations between unions and employees. Her classes discussed arguments for and against compulsory trade unionism, a hotly debated subject in New Zealand throughout 1986. Ms Woods explained a variety of words used with reference to unions, and encouraged students to interview workers to get first-hand interpretations of such concepts. She also tackled the issue of low female representation in trade union activities.

While the opportunity was only rarely exploited, trade unionism as a movement therefore provided a space for some teachers, although not for a school or schools collectively, to focus on class-related inequalities and on the struggle throughout New Zealand's history to claw back human rights from a capitalist environment. Much more collective were efforts to address another structure of oppression, of its nature more visible in New Zealand. I am referring here to racial oppression, and it is to teachers' and schools' efforts to confront this situation that we now turn.

\section{Ethnic rights movement}

Currently in New Zealand the ethnic rights movement generally, and the Maori movement in particular, are often considered to be the most powerful and visible of social movements. It has found in such people as Donna Awatere (1984) and Ranginui Walker (1987), powerful and articulate spokespersons to spearhead a general renaissance in art, culture, language and identity. The material and spiritual conditions of oppression by the Pakeha (white people) have laid the ground for reaction, and increasingly the tangata whenua - or original people of the country are looking towards independence as regards economic, cultural and educational development.

A brief look at some statistics sets the scene for the so-called Maori problem. A background paper prepared by the Department of Labour for the Maori Economic Summit of October 1984 showed that the unemployment rate for Maoris was 2.4 per cent in 1951, while the rate for non-Polynesians was 1.3 per cent. This gap had widened to a fourfold difference by 1981, with rates of 14 and 3.5 per cent respectively. Census figures (Statistics Department, 1986) show that almost 15 per cent of the Maori labour force is unemployed, against 6 per cent of non-Maori workers. Brosnan (1986) has shown that those who do find work do so in a very restricted range of peripheral, low-status jobs in the secondary sector of the labour market. One can therefore speak of 'job apartheid' in New Zealand.

In education, Maori students represent a very high national drop-out rate, and achievement is low: 65 per cent left school in 1982 without any qualifications, compared to 27 per cent of Pakeha students (NZ.DoE, Education Statistics, 1984). 49 per cent of Maori students become unemployed on leaving school (NZ.DoE, 1984).

Waldegrave and Coventry (1987) have claimed that 30 per cent of New Zealand's population live in poverty, with 'poverty' being defined as homelessness, lack of adequate housing, food, health care, and not having a minimum amount of money for recreation. The poor in New Zealand have to choose between shelter and subsistence. Waldegrave and Coventry show that there is nothing indiscriminate about poverty, with groups characterized by race and gender figuring disproportionately in statistics related to poverty indices, such as lack of housing, low income, and unemployment. 
Practically all three schools, located in one of the heartlands of Maoridom, had to face the challenge of Taha Maori (Maori culture generally). Such an involvement was set into motion by the National Curriculum Review exercise, an initiative of the Labour government, itself ostensibly sympathetic to Maori rights, and which deliberately put questions regarding multiculturalism on the agenda (NZ.DoE, 1986).

However, while both All Boys' College and All Girls' High addressed some of the issues during staff seminars, for instance, it is Co-Ed High that is singled out as being the best example of the three to illustrate how schools can be caught up in social movements. It was the school's policy deliberately to attract a high percentage of Maori and Polynesian students - 30 per cent compared to 11 per cent at All Girls' High and 3 per cent at All Boys' College. Maori students at those last two schools told the researcher that they had done their best to get transferred to Co-Ed High: they felt that they would feel more comfortable there with so many Maori students around. State school inspectors visiting the two single-sex schools in the study pointed at Co-Ed High as a model and guide for their efforts to introduce biculturalism.

Co-Ed High showed its commitment to biculturalism in a number of ways. The school strove to raise consciousness and attack prejudice through projecting a specific material environment which showed the high status the school wished to bestow on things Maori. Maori carvings and designs had pride of place in a number of the school's buildings. A marae (or traditional Maori community-house) was in the process of construction on the school grounds, and the work received widespread media coverage with a short documentary being filmed and shown on the national television network. The school received moral and financial support from local Maori communities, the Maori Queen, and the Minister of Maori Affairs who visited it during 1986. Staff, students and parents used the marae frequently and were taught the significance of the art work by the master carver and his team. Thus, the building itself was used to give powerful exposure to Maori values, beliefs and customs.

Pakeha as well as Maori students were found to use the marae space. Said one working-class Pakeha fourth-former: 'Down on the marae it's good, because you're treated equal. It's all one big family down on the marae... we go down there for New Zealand studies, and we watch the carvers at work.' Monthly gatherings for large sections of the school population were organized and Maori students took leadership roles in singing Maori songs, the school hymn in Maori, and expressing their culture through ritual speeches and dance.

The principal, a Pakeha, invariably spoke and wrote Maori at the start and finish of every address to students and parents. One Maori student said: 'It gives us a warm feeling when you see a Pakeha talk Maori. It's just like a new-born baby... you know ... of giving a new life to the language... giving it life.' On major occasions, Maori elders from the community were invited to speak to students, and this was always accompanied by Maori traditional dancing and song. Both the head boy and head girl elected by students were Maori, and identified themselves as such.

There was a generally felt need by the staff not only to learn about biculturalism but also to become bicultural. The two Maori teachers, who had high status among teachers and students alike, taught the staff about cultural differences, how such differences could affect learning, and organized marae events for staff and students to experience the differences and hence 'understand with head and heart'. Taha Maori infiltrated the curriculum in practically every subject. Obvious examples were Maori literature in translation in English classes, and a consideration of New Zealand history from a Maori point of view.

142 Research Papers in Education Volume 6 Number 2 
A six-month unit, compulsory for practically all the school and called New Zealand studies', introduced aspects of Maori culture and myths to students, and those who wanted could opt for a more intensive course in Maori language and culture. Radical experiments with the curriculum were being planned for maths and science by the Maori teachers who, along with all the staff, were aware of the minority of Polynesian students taking the subjects. Staff were generally anxious because, by dropping such subjects, future life-chances, both educational and occupational, were severely limited. Such experiments included the developing of maths and science skills through the construction of traditional Maori artefacts. Through the Maori culture group, the Maori members of staff cared for and encouraged Maori students to 'hold their heads high', to feel good about themselves and their identity as the tangata whenua of Aotearoa.

This is not to suggest that Co-Ed High had found a way to transform the racism. generally observed within schools, let alone in the wider community, or the problems such racism created for its victims. Maori students at Co-Ed High still found schooling generally irrelevant, though much less frustration and cynicism was expressed at this school than at the others. Pakeha and Maori students still tended to sit separately in the field during recreation time. Maori parents attended parents' evenings less frequently than their Pakeha counterparts, and difficulties in coping with uninterested Maori students in classrooms often created unhappy teachers. A small but influential group from the staff were critical of biculturalism, and were often referred to by more progressive staff as the 'official opposition'. However, it is also true that Pakeha students, and staff, were challenged daily to face up to their prejudices and to become more human. The verdict of one Maori elder in the community was: 'Maori kids here are much more confident in this school... you go to Blenheim High, and [the Maori students there] are very head down for shame.'

\section{... AND TEACHERS}

In this subsection I will identify teachers from Co-Ed High and All Girls' High who were generally more radical in their approach to biculturalism. While supporting their respective schools' initiatives, these teachers were more ready to consider the integrationist elements of liberal biculturalism, and the possibility that such initiatives could serve as a form of sophisticated social control. They were also generally more willing to link culture with its broader political implications and to consider how racial inequality and violence were embedded in the very structure of New Zealand society. The three Maori teachers observed and interviewed - two of whom were at Co-Ed High and the other at All Girls' High - were much more direct and scathing about past colonial violence. Said one of them, recalling that a great ancestor from his tribe had advocated accepting the Pakeha system to succeed in it: 'We think we have moved far enough to the middle ground... it is now the turn of the Pakeha.'

They were also much more ready to blame systems rather than the victims. Referring to the Pakeha staff at All Girls' High, a Maori teacher said:

Sometimes I get exhausted... not because of the kids, but because of the battle of trying to instil into these people over there in the staffroom that what they are doing is wrong. There are a lot of things I don't agree with, and I think it's terrible what some of the teachers are doing to the Maori kids. The girls tell me, and I say to them: 'Ah well... don't you answer them back, don't you fight them... That's my job. I'll go and ask them, and I'll ask them nicely... and if they're rude to me, I can be as rude as I like back to them. I'm a teacher, and if they want to be rude to me, I can be twice as rude to them, because I know how to do it because I've taught with them for so long!' 
A Pakeha teacher at Co-Ed High, a radical feminist of working-class roots, felt that even at her school, while people's consciousness was raised:

... change doesn't happen in the structures often. So the timetabling and giving space to do things differently, like having alternative ways of organizing meetings and running classrooms...the idea of experts... that's not often addressed, or modes of learning. For example, the Maori word ako to learn is also to teach. It's one word.

Despite the obvious limitations with liberal models for transformative activity, it is important to note that in this case not only individual teachers but staff collectively addressed democratic issues in an organized manner and attempted to mobilize education for equitable ends. Another instance of school involvement with progressive social movements refers to women's struggle for equality in a variety of social sites. It is to an illustration of this that we now turn, with special attention being put on counter-hegemonic school-to-work messages.

\section{Feminism}

Feminism in New Zealand is combating the same oppressive conditions that women suffer in other parts of the 'Western' world, and a variety of research exists as evidence to the Antipodean version of the subordinate position of women in various spaces in the social arena (see inter alia Olssen, 1981; Hyman, 1981). Women in New Zealand are thus grossly over-represented in low-skilled, low-paid, low-status jobs; they earn half the average income of men despite equal-pay legislation; and are found in peripheral and insecure positions in the labour market, and among the unemployed. The situation for ethnic 'minority' women is even more desperate, carrying as these do the double burden of racist and sexist oppression.

Within education, Middleton (1984) has noted a positive effect of the 'second wave' of feminism: this has led to an increased general awareness of the extent of inequality between the sexes in schools and the wider society. She also notes, however, that some of the gains made by women in schools are being eroded under the influence of various right-wing groups, including certain fundamentalist Christian groups and educational pressure groups such as the Concerned Parents' Association. The economic crisis has also provided an excuse for cuts in education, one result of which was the suppression of virtually the entire structure within the Department of Education for affirmative action for women and girls in 1982.

\section{SCHOOLS....}

All Girls' High School had explicitly set out to confront - and to 'conscientize' its students about - discrimination against women. The ways and means adopted, as well as an evaluation of such efforts are presented in more detail in another paper (Sultana, 1990b). In this context it is important to mention some of the initiatives found at this school. Thus there was the transformation of the material school environment by a single-minded principal and staff, such as: the setting up of a workshop complex; the placement of women in positions of responsibility; and the promotion of the view that 'Girls can do Anything' through pictures, charts, posters, newspaper cuttings and stickers in staffrooms, classrooms, canteens, assembly hall, and on notice-boards and school-bags.

144 Research Papers in Education Volume 6 Number 2 
All these initiatives were intended to raise students' consciousness about issues relating to women and work - such as equal pay for equal work, the value of unpaid labour, sexist behaviour and discrimination, as well as harassment on the work-force - within the official curriculum and during activities such as seminars, camps, and career conventions. Considerable pressure was put on the students to include mathematics and science in their course of studies. Meetings were held with parents over the year, but especially so when it came to students choosing subject options, with the intent of pointing out the effect on their daughters' life-chances of particular choices and decisions. Newsletters sent by the school to parents often gave similar messages. The principal and staff also used the city's media, including the radio station, to promote feminist concerns among a wider group of people. The following statement made by the principal during a staff meeting could be taken to fairly represent what the school set out to achieve:

My dream is that all the girls will walk out of school standing tall . . I want the girls in the school to care about people and to care about themselves as people. We want them leaving here standing tall, striding into their futures.

Despite the fact that students resisted some feminist-informed messages, acceptance was much more common among senior students. This points towards the effectiveness of the school ethos in forming the subjectivities of students. As fifthformers from this school said:

They really tell us about jobs that aren't traditional, and that some girls might be afraid to ask about them or don't actually realize that they'd like that job because they never thought they could do something like that... They've been opening new doors, saying 'So what if guys have traditionally done this?! You are capable of it too. If you want to do it, go ahead and do it!'

\section{... AND TEACHERS}

While the school's efforts were mainly liberal rather than radical in intent - and were therefore ultimately ineffective in addressing structures outside of the school which coopted and hemmed in their efforts - individual teachers more directly linked with grass-roots feminist movements and groups were observed to express other concerns. Ms Woods, for instance, felt that the liberal campaign failed to take into account the confluence of class and ethnic issues and hence it obliquely mirrored the oppressive system it was criticizing by being insensitive to the everyday realities of working-class and ethnic persons.

While similar but much less extensively organized and coordinated efforts took place at Co-Ed High, the same problem of liberalism cropped up there too. One feminist teacher at this school spoke of the liberal rather than radical perspectives prevailing, and judged this to be

... a glossing over... to me, to be radical is to be different at the root, to see things quite differently, and what happens a lot is we see things nicely rather than seeing things as conflict or confrontationally... We want to be 'nice' and 'mature' and 'adult'. So we tend to gloss over.

She herself gave more penetrating messages about structural violence perpetrated on women in New Zealand, and chose literature texts that raised her students' 
consciousness about a variety of issues. Students in fact referred to her as an outstanding person who constantly challenged their common-sense views.

\section{Liberationism}

Strictly speaking, it is inappropriate to speak of liberationism - a movement moulded by a creative dialogue between Marxism and radical Catholicism and finding formal expression in 'liberation theology' (see inter alia Gutierrez, 1974) within the New Zealand context, and far away from its Latin-American roots. However, it is argued that religious movements in New Zealand as elsewhere are subject to not only reactionary agendas and inspirations, but also to progressive and even radical ones. While it is well known that the official ideology of the Catholic church is inspired by a personalist philosophy (Kovel, 1987), it is also true to say that the church, like any other social institution, has a number of voices despite the 'catholicism' (that is, doctrinal universality and sameness) that its pontiff would like to impose.

Reflections of liberationism can be gleaned at All Boys' College, even if the images that arose were, at the time the study was carried out, mere phantoms of intentionality. The school therefore had an overtly progressive, even radical, manifesto which was meant to represent its 'special character'. This document defined the school's undertaking in terms of a practical education which manifested itself through 'action, participation and vital contact with the reality of injustice'. This document also urged the school's teachers to defuse competition, respect differences, foster cultural groups, find work for unemployed, provide experiences of success for each, educate to change society and not merely to fit into it, to denounce and resist where necessary, to highlight social injustices such as racism, to provide media education, and finally to teach change-agent skills.

That the inspiration behind such a document was liberationism became obvious in the course of a number of meetings with the three Brothers who taught and led the College. These Brothers need to be singled out from the rest of the staff, the Board of Governors of the school, and the parents because they were practically alone in appreciating the transformative potential of education. I discovered, for instance, that the Order in which these Brothers were had that very same year chosen 'social justice' as the guiding theme for their work within schools and in other social sites. They had all done what they referred to as 'structural analysis' courses to discover who in New Zealand had power, how it had been obtained, and on whose behalf it was being used. The principal spoke of the need for his staff - used to working almost exclusively with well-off, middle-class white boys - to unblinker themselves. He was aware that the school was 'light years behind in the whole area of social justice', noted that 'the lessons of Paolo Freire had a tremendous influence on catholic schools in Australia ... and that's where we have to look at'. He asserted:

It's the powerless we should be working with, and in the future, all of the areas where the Brothers are involved will be subject to a process of structural analysis, and where the structure won't be changed by our pressure, we'll move off to an area where we can change.

He spoke of a deliberate policy to increase the number of 'needy boys' at the school. Another Brother, in charge of teaching religious instruction, spoke of his intention to include a social justice component, and to introduce issues about racism, peace and sexism. A third Brother had run a course on Maori culture and planned to run it again the following year, even though he felt disillusioned by the students' resistance to it. 
Indeed, the fact that the most hegemonic, reactionary, sexist, racist and élitist attitudes were noted at this school often made me wonder how the most overtly progressive and political school agenda could rest in tandem with the reality that epitomized the very same injustices that the school overtly set out to eradicate in the first place. It was discovered that the Brothers were ahead of most of their staff, the Board of Governors, and parents, and had to compromise in order to gradually carry the rest with them. Staff were encouraged to take courses in Maori language and were chided for their sexism in staffroom interaction. Parents were exposed to biculturalism at a Silver Jubilee mass - even though some became angry when a Maori lady sang a traditional chant, and one parent was overheard exclaiming: "What's this fuckin' Maori doing in Church? They don't have bells in maraes!' As the principal said with regard to his religious teaching order: "There is this feeling that if we tried to run a Catholic school as we believe it should be run, we would lose three-quarters of our roll within a year or two.'

The Brothers had problems in asserting their agenda for other reasons too: there were two cases recorded, and others reported, where parents wrote letters of protest when teachers presented opinions and ideas sympathetic to progressive agendas like equitable re-distribution of wealth (during a history course). The principal had to warn parents at the end-of-year prize-giving ceremony that there was a small but growing group of Catholics "who have borrowed many of the approaches and methods of the American Moral Majority with its narrow fundamentalism, its rejection of the rights of the individual, a suspicion of the intellect and a most unChristian belief that tolerance of diversity is a snare of the devil'. He was also hemmed in by the Chairman of the Board of Governors, whose position as foremost employer of Catholics made him the most influential power-broker in the city's Catholic community, and a stalwart leader of conservative elements of the church. Again, the end of the year saw the principal trying to steer the school towards the declared ethos with the help of a 'hand-picked' and new Chairman and members. Finally, the falling short of the moral target could also be attributed to a strategem used by the hierarchy of the New Zealand Catholic church and reported by a key informer within the school - the transfer of Brothers and Sisters to rural regions as punishment for being politically involved in controversial issues.

While hegemonic forces were most in evidence at All Boys' College, it would be glossing over conflict and contradictions to dismiss transformative possibilities quietly, at times even anxiously, waiting to break out. Thus, one teacher commented that while none of the Brothers had been 'sufficiently charismatic to attract around them a large number of kids or parents, still they're moving beyond what most parents would accept as reasonable for their sons to learn'.

\section{The Peace Movement}

New Zealand has earned an international reputation for its stand against nuclear energy, and the declaration of its territory as a nuclear-free zone. Highlights of this policy throughout the years when the present research was being carried out included Prime Minister Lange's internationally publicized debate on the subject at Oxford University in Britain; his government's refusal of permission for entry into its ports of American nuclear-capable ships (with subsequent retaliation by the United States who considered this a breach of the ANZAC alliance); frequent denouncements against France for its nuclear testing at Mururoa Atoll, and finally the outrage at the French terrorist attack on the Rainbow Warrior, a ship used by the Greenpeace Movement to protest against French nuclear testing in the Pacific. 
No school developed a generally powerful analysis of the politics of peace, although All Boys' College had invited a member of the Peace Movement to give a series of talks, which, according to the principal, turned out to be unsatisfactory due to their anti-American, pro-Soviet stance. Co-Ed High had some years earlier declared itself a nuclear-free zone, and a group of teachers from the school wrote to Le Monde (a French newspaper) to protest about the 'Rainbow Warrior affair'. The school's generally progressive policies attracted a number of radical teachers, one of whom was an active member in the local branch of the Peace Movement. As a part-time teacher of geography, he gave cyclostyled notes taken from Andre Gunter Frank's Latin America: Underdevelopment or Revolution and Eduardo Galeano's Open Veins of Latin America: Five Centuries of the Pillage of a Continent. He introduced one lesson thus:

I have taken a number of extracts chiefly to draw your attention to the fact that there is another perspective to the one we most commonly get. Most importantly, it is a perspective which is sympathetic to, firstly, the people of the so-called Third World countries, and secondly and more importantly, those who are powerless. I recommend to you the view that if you really want to know what is going on, then go ask those who are hurting, those who are powerless and oppressed. Don't ask the decision-makers, the powerful, the oppressors.

While he felt that he was practically alone in giving these sorts of messages, and that few students were ready to think along these lines ('Except one Maori lad'), yet nevertheless he felt free to raise consciousness at Co-Ed High and not elsewhere.

\section{Discussion and conclusion}

While I have taken pains to document inter- and intra-school differences and the spaces these allow for transformative education, I need to reiterate that the general tenor of the three schools observed was hegemonic. As suggested in the Introduction, that this is so is not necessarily the responsibility of teachers as such. The teachers' individual and collective, liberal progressive (at times radical) voices have been identified, but in so doing, some of the limits imposed on them by structural constraints have also been singled out. One teacher expressed such constraints well when she said: 'There is a silencing that operates on us all, doesn't matter where we are. We get silenced. Lots of people get silenced. The structures are too big, the powers are too strong.' Another teacher commented sadly about how the school structures forced him to jettison values, such as the sharing of authority with students: 'So you enter the structure and bang go your values, because how are you going to run a programme with 25 very different people?! The structures do violence on us as much as on the students!'

It takes a very special set of circumstances so that socially critical voices first of all emerge from a distinctly middle-class group of workers, and secondly that such voices survive the silencing that follows pre-service training and in-service labour conditions. From the data presented in the foregoing sections, it would appear that the chances of this happening increase when teachers are unified and organized behind an ideal. It has been argued that those teachers who have been 'conscientized' around ideals of social justice by their membership, official or otherwise, within social movements, can (and in the cases cited above, are) having a positive, democratizing effect on schools. They are also affecting the wider social formation through 'the production of forms of consciousness - ideas, feelings, desires, moral preferences, knowledges, forms of consciousness of self (Johnson, 1980, p. 11). While some authors, notably Giroux

148 Research Papers in Education Volume 6 Number 2 
(1983), have argued that teachers need to work for democracy in schools and extend their efforts into other areas of the 'public sphere', it would appear that the process, when it does happen, takes place the other way around. Those teachers who do become politicized seem to do so through their involvement in extra-school activities - and social movements primarily so. The insights generated there subsequently reflect on their work within schools.

This study has implications beyond the identification of some of the conditions which make critical and anti-hegemonic education possible and probable in schools. A novice initiated into the theoretical literature that critically analyses the links between education and the wider social order would be forgiven if his or her ultimate feeling would be a sense of almost total pessimism about teachers' potential contribution to social transformation. While structuralist-functionalist reproduction paradigms have been problematized by an insistence on agency, yet, as Petitat (1987) has pointed out, 'reproduce' remains the master word and key paradigm in the sociology of education. Carlson (1987, p. 291) notes that such a view leads to a pessimism 'that the Left should do its utmost to fight rather than encourage'.

This should not be interpreted as an invitation to a ritualistic belief in 'positive thinking'. Rather, what is being argued here is that (a) justice needs to be done to the complexity and contradictions in social sites, so that competing voices are actually identified; and (b), it is an important task for researchers from the Left to describe and carefully analyse successful transformative attempts within schools (and other social sites). This must be part of a wider effort, what Gramsci (1971) calls the 'war of position', whereby the organic intellectual builds an arsenal of attack leading to an 'intellectual and moral revolution'. If we are to describe failed attempts, let us then not go into the 'teacher bashing' which, as Apple (1986) points out, has characterized many accounts of teachers' work. It is much more constructive to look at the material and ideological constraints that foiled such attempts, and to devise politically conscious strategies to overcome these and other limitations.

Scholars and researchers within the radical tradition need to understand and sympathize with the genuine efforts of teachers like those described above, who are 'attempting to make a life [they] can be proud of out of the fragments of history which [they] can win some command over' (Inglis, 1985, p. 58). More than that, transformative researchers need to work on the project of identifying individuals and groups of teachers engaged in emancipatory interests or involved in exercising liberating actions. They would then offer their support, and share knowledge and insights in carrying out concrete analyses of the power layers within a situation, helping to tilt the balance in favour of the oppressed. They would make students' contestations a vailable to teachers offering insights leading to reflexivity and praxis. In other words, the researcher would be involved in the sort of Freirian pedagogy advocated for teachers, appropriating various democratic and emancipatory voices, and introducing themes that heighten the chances for a truly critical education to occur. As Burbules (1986) notes, this is a crucial theoretical and political shift which is suggested for future educational research, because it moves from studying and understanding the prospects of reform in schools in favour of advocating such reform, insisting on its possibility, and becoming actively involved in making the possible probable. There is skill in the ethnographer's depiction of life. The genius of the critical researcher will be to act as a midwife in the transformation of that life to a version that is more democratic, equitable and just. 


\section{Acknowledgements}

I would like to record my gratitude to P. D. K. Ramsay and E. J. Wadsworth, Dean and Senior Lecturer respectively, at the University of Waikato, New Zealand, for their comments on earlier drafts of this paper.

\section{References}

ANYON, J. (1980). 'Social class and the hidden curriculum of work', Journal of Education, 162, $67-92$.

ANYON, J. (1981). 'Social class and school knowledge', Curriculum Inquiry, 11, 3-42.

APPLE, M.W. (1982). Education and Power. London: Routledge and Kegan Paul.

APPLE, M. (1986). 'Review of R. W. Connell's Teachers' work', Comparative Education Review, August, 454-6.

ARCHER, E. and OPENSHAW, R. (1986). "Citizenship and identity as "official" goals in social studies', New Zealand Journal of Educational Studies, 21, 55-65.

ASHENDON, D., CONNELL, B., DOWSETT, G. and KESSLER, S. (1987). 'Teachers and working class schooling'. In: LIVINGSTON, D.W. (Ed) Critical Pedagogy and Cultural Power. South Hadley, Ma: Bergin Garvey.

AWATERE, D. (1984). Maori Sovereignity. Auckland: Broadsheet.

BATTERSBY, D. (1981). The first year of teaching. Unpublished DPhil thesis, University of Waikato, Hamilton, NZ.

BEDGGOOD, D. (1980). Rich and Poor in New Zealand: A Critique of Class, Politics and Ideology. Auckland: Allen and Unwin.

BOSHIER, R. (1973). 'Conservatism within families: a study of the generation gap'. In: WILSON, G.O. (Ed) The Psychology of Conservation. London: Academic Press.

BRAITHWAITE, E. (1984). 'Teaching as a profession'. In: RAMSAY, P.D.K. (Ed) Family, School and Community. Sydney: Allen and Unwin.

BROSNAN, P. (1986). Maori Occupational Segregation. Working Paper No. 2. Industrial Relations Centre, Victoria University of Wellington, NZ.

BURBULES, N.C. (1986). 'Review article: Education under siege', Educational Theory, 36, $301-13$

CARLSON, D. (1987). 'Teachers as political actors: from reproductive theory to the crisis of schooling', Harvard Educational Review, 57, 283-307.

CARNOY, M. (1983). 'Education, democracy and social conflict', Harvard Educational Review, $53,401-2$.

CARNOY, M. and LEVIN, H. (1985). Schooling and Work in the Democratic State. Stanford, CA: Stanford University Press.

COLE, M. (1984). 'Teaching till two thousand: teachers' consciousness in times of crisis'. In: BARTON, L. and WALKER, S. (Ed) The Social Crisis and Educational Research. London: Croom Helm.

CONNELL, R.W. (1985). Teachers' Work. Sydney: Allen and Unwin.

CONNELL, R.W., ASHENDEN, D.J., KESSLER, S. and DOWSETT, G.W. (1982). Making the Difference. Sydney: Allen and Unwin.

EISNER, E.W. (1985). The Educational Imagination. New York: Macmillan.

FRANK, A.G. and FUENTES, M. (1987). 'Nine theses on social movements', Economic and Political Weekly, August 29.

GASKELL, J. (1986). 'The changing organisation of business education in the high school: teachers respond to school and work', Curriculum Inquiry, 16, 417-37.

GIROUX, H.A. (1983). Theory and Resistance in Education. South Hadley, MA: Bergin and Garvey.

GIROUX, H.A. (1988). Teachers as Intellectuals. South Hadley, MA: Bergin and Garvey.

GLASER, B.G. and STRAUSS, A.L. (1967). The Discovery of Grounded Theory. Chicago, IL: Aldine.

150 Research Papers in Education Volume 6 Number 2 
GRAMSCI, A. (1971). Selections from the Prison Notebooks, HOARE, Q, and NOWELLSMITH, G. (Ed/trans). London: Lawrence and Wishart.

GRIFFIN, C. (1985). Typical Girls? London: Routledge and Kegan Paul.

GUTIERREZ, G. (1974). A Theology of Liberation. London: SCM Press.

HARGREAVES, A. (1984). 'Experience counts, theory doesn't: How teachers talk about their work', Sociology of Education, 57, 244-54.

HYMAN, P. (1981). 'Women's labour force participation in New Zealand'. In: Women's Studies Conference Papers. Auckland Women's Studies Association (N.Z.) Inc.

INGLIS, F. (1985). The Management of Ignorance. Oxford: Basil Blackwell.

JOHNSON, R. (1980). 'Cuitural studies and educational practice', Screen Education, 34, 5-16.

JONES, A. (1986). At school I've got a chance: Social reproduction in a New Zealand secondary school. Unpublished DPhil thesis, Auckland University, NZ.

KOVEL, J. (1987). 'The theocracy of John Paul II'. In: MILLIBAND, R. PANITCH, L. and SEVILLE, J. (Ed) Socialist Register: Conservatism in Britain and America: Rhetoric and Reality. London: Merlin Press.

LAUDER, H.C., HUGHES, D.C. and TABERNER, S.J. (1985). 'Education, class and inequality in New Zealand: a preliminary report', Delta, 36, 31-7.

LIND-BRENKMAN, J. (1983). 'Seeing beyond the interests of industry: teaching critical thinking', Journal of Education, 165, 283-94.

MERCURIO, J. (1975). 'Teacher perspectives on corporal punishment'. In: RAMSAY, P.D.K. (Ed) The Family and School in New Zealand Society. Melbourne: Pitmans.

MIDDLETON, S.C. (1984). 'Towards a sociology of women's education in New Zealand'. In: RAMSAY, P.D.K. (Ed) Family, School and Community. Sydney: Allen and Unwin.

MILIBAND, R. (1987). 'Class analysis'. In: GIDDENS, A. and TURNER, J. (Ed) Social Theory Today. Cambridge: Polity Press.

NEW ZEALAND. DEPARTMENT OF EDUCATION (1984). Education statistics of New Zealand, 1963-1984. Wellington: Government Printer.

NEW ZEALAND. DEPARTMENT OF EDUCATION (1986). Learning and Achieving. Wellington: Government Printer.

OLSSEN, E. (1981). 'Truby King and the Plunket Society: an analysis of a prescriptive ideology', New Zealand Journal of History, 15, 1.

PETITAT, A. (1987). 'School and the production of society', British Joumal of Sociology of Education, 8, 379-90.

POULANTZAS, N. (1975). Classes in Contemporary Capitalism. London: New Left Boors.

RAMSAY, P.D.K. (1978). The Great Student Ripoff? Lukes' Third Dimension of Power in Action in a Teachers' College and School of Nursing. Paper presented to SAANZ Conference, Brisbane (May).

RAMSAY, P.D.K. (1983a). 'Autonomy of New Zealand teachers: there's a fraction too much friction', Delta, 32, 17-33.

RAMSAY, P.D.K. (1983b). 'Fresh perspectives on the school transformation - reproduction debate: a response to Anyon from the Antipodes', Curriculum Inquiry, 13, 295-320.

RAMSAY, P.D.K., SNEDDON, D.G., GRENFELL, J. and FORD, I. (1983). "Successful" vs "unsuccessful" schools: a South Auckland study', Australia and New Zealand Journal of Sociology, 19, 217-34.

SACHS, J. and SMITH, R. (1988). 'Constructing teacher culture', British Joumal of Sociology of Education, 21, 423-36.

SHILLING, C. (1987). 'Work-experience as a contradictory experience', British Journal of Sociology of Education, 8, 407-23.

SPOONLEY, P. et al. (1982). New Zealand: Sociological Perspectives. Palmerston North: Dunmore Press.

STEVEN, R. (1978). 'Towards a class analysis of New Zealand', Australia and New Zealand Journal of Sociology, 14, 113-29.

SULTANA, R.G. (1987). Schooling for work in New Zealand: a qualitative study of three high schools. Unpublished DPhil thesis, University of Waikato, NZ.

SULTANA, R.G. (1988a). 'Schooling tomorrow's worker: trade union education in secondary schools', New Zealand Journal of Industrial Studies, 13, 3-20. 
SULTANA, R.G. (1988b). 'Ethnicity and the reproduction of labour market locations: do Maori students really have a choice?', Delta, 40, 51-68.

SULTANA, R.G. (1989). 'Transition education, student contestation and the production of meaning: possibilities and limitations of resistance theories'. British Journal of Sociology of Education, 10, 287-309.

SULTANA, R.G. (1990a). 'Gender, schooling and transformation: evaluating liberal feminist action in education', New Zealand Journal of Educational Studies, 25, 5-26.

SULTANA, R.G. (1990b). "It's who you know, not what you know": penetrating the credentialling ideology', British Journal of Guidance and Counselling, 18, 51-65.

SULTANA, R.G. (1990c). 'Schooling for work in New Zealand: reproduction, contestation and transformation in three high schools', British Journal of Education and Work, 3, 35-48.

TOWER, M. (1978). 'The political socialization of New Zealand schoolchildren'. In: LEVINE, S. (Ed) Politics in New Zealand: A Reader. Sydney: George Allen \& Unwin.

WALDEGRAVE, C. and COVENTRY, R. (1987). Poor New Zealand. Wellington: Platform Publishing.

WALKER, R.J. (1987). Nga Tau Tohetahe: Years of anger. Auckland: Penguin.

WILLIAMS, R. (1978). Marxism and Literature. London: Oxford University Press.

WILLIS, P. (1977). Learning to Labout. Farnborough: Saxon House.

WRIGHT, E.O. (1983). 'Giddens' critique of Marxism', New Left Review, 138, 11-35.

\section{Correspondence}

Dr R.G. Sultana, Department of Educational Studies, Faculty of Education, University of Malta, Msida, Malta. 